\title{
JUBULA HUTCHINSIAE SUBSP. CAUCASICA SUBSP. NOV. (JUBULACEAE, MARCHANTIOPHYTA) - A NEW TAXON FROM THE WESTERN CAUCASUS
}

\section{JUBULA HUTCHINSIAE SUBSP. CAUCASICA SUBSP. NOV. (JUBULACEAE, MARCHANTIOPHYТА) - НОВЫЙ ТАКСОН С ЗАПАДНОГО КАВКАЗА}

\author{
NADEZHDA A. KONSTANTINOVA ${ }^{1} \&$ ANNA A. VILNET ${ }^{1}$ \\ НАДЕЖДА А.КОНСТАНТИНОВА ${ }^{1}$, АННА А.ВИЛЬНЕТ ${ }^{1}$
}

Abstract

Jubula hutchinsiae (Hook.) Dumort. subsp. caucasica Konstant. \& Vilnet is described based on ITS1-2 nrDNA, trnL-F and trnG cpDNA sequences and some morphological differences. Detailed description of the subspecies is provided, taxonomy, ecology and distribution of the taxon are discussed.

Резюме

На основе анализа сиквенсов ITS1-2 ядерной ДНК, $\operatorname{trn} \mathrm{L}-\mathrm{F}$ и $\operatorname{trn} \mathrm{G}$ хлоропластной ДНК и небольших морфологических отличий описан новый подвид Jubula hutchinsiae (Hook.) Dumort. subsp. caucasica Konstant. \& Vilnet. Приводится детальное описание таксона, обсуждаются таксономические особенности, экология и распространение подвида.

KEYWORDS: hepatics, Jubulaceae, Jubula, molecular phylogenetics, nrITS, trnL-F, $\operatorname{trn} \mathrm{G}$, Caucasus

\section{INTRODUCTION}

Jubula Dumort. is an oligotypic genus with temperate - tropical distribution. As it was noted by Zerov (1953), "there is a real mishmash in the treatment of species of this genus" (translation from the Ukrainian). After nearly 60 years this observation remains valid.

During a study of hepatics from the Caucasus the first author collected 32 specimens of Jubula in different regions of the western Caucasus (fig. 1). Following Guerke (1978) the specimens were identified as Jubula hutchinsiae (Hook.) Dumort. subsp. javanica (Steph.) Verd. but doubt about the correctness of this decision remained.

Jubula was first reported for the Caucasus from the territory of Georgia by Brotherus (1892) as Frullania hutchinsiae (Hook.) Nees var. integrifolia (Nees) Lindb. Later Verdoorn (1930) re- ported Jubula hutchinsiae (Hook.) Dumort. subsp. javanica (Steph.) Verd. for the Caucasus based on a collection of Voronov. Two species of Jubula were carefully described and illustrated in the treatment of the genus for the territory of the former USSR by Zerov (1953). J. pennsylvanica (Steph.) A. Evans was reported by Zerov (1.c.) for three localities in the Caucasus in Adzharia, Abkhazia, and the Krasnodar Territory in Russia) whereas J. japonica Steph. was reported from two localities in the Primorsky Territory based on specimens collected by Lazarenko (1936). Zerov (1953) referred all records from the Caucasus including his own ones to $J$. pennsylvani$c a$ because the Caucasian plants are characterized by almost totally entire margins of leaves and underleaves. The second important argument was temperate distribution vs. tropical for Jubula hutchinsiae subsp. javanica. In his monograph

1 - Polar-Alpine Botanical Garden-Institute of Kola Sci. Center of RAS, Kirovsk, Murmansk Province, 184256, Russia - Россия, 184256, г. Кировск, Мурманская область, Полярно-альпийский ботанический садинститут им. Н.А. Аврорина Кольского НЦ РАН E-mails: nadya50@list.ru \& anya_v@list.ru 


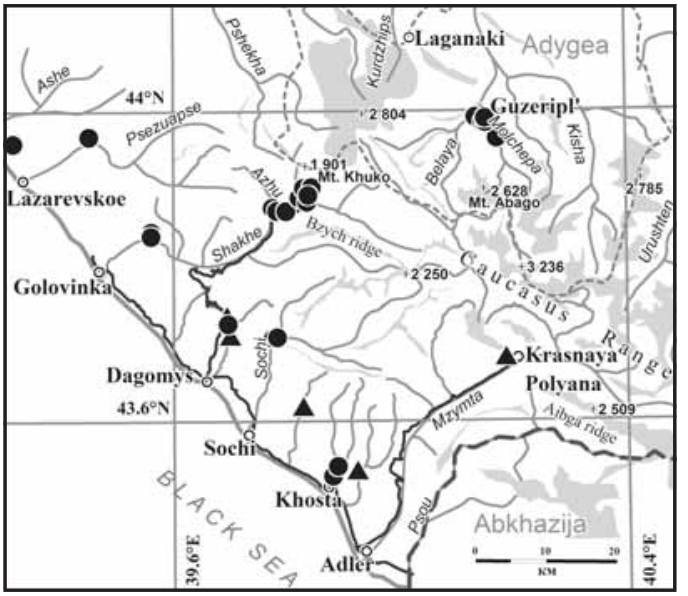

of the genus Jubula Guerke (1978) stated that $J$. pennsylvanica is an American endemic and referred the specimens from the Caucasus that he had studied to J. hutchinsiae subsp. javanica. In the 1980s $J$. pennsylvanica was reported again by Duda (1982) from several localities on the slopes of the Caucasus facing the Black Sea. J. hutchinsiae subsp. javanica is recorded for the Caucasus in all recent check-lists and publications (Düll, 1983, Konstantinova et al., 1992, Schumacker \& Váňa, 2005, Konstantinova \& Bakalin, 2009, Konstantinova et al., 2009 etc.) based on Guerke's revision of Jubula (Guerke, 1978).

Several papers devoted to the study of Jubula have been published recently. Indian bryologists (Dey et al., 2011) reported J. pennsylvanica for Himalaya as the first Asian record of the species providing an identification key for Asian taxa of Jubula. Japanese bryologists (Katagiri et al., 2010) proposed new diagnostic features for differentiating the taxa of Jubula based on study of a vast material from Japan and Taiwan, including size and shape of male branches, degree of thickness of cell walls in cross section of stem, etc. As a result they treated J. hutchinsiae subsp. javanica as a separate species and provided the original key for distinguishing of the three discussed species: J. hutchinsiae, J. javanica, and J. japonica. Pätsch et al. (2010) suggested a great molecular diversification based on a molecular study of a large set of specimens of Jubula, but calculation of overlapping morphological features lead them to treat both $J$. pennsylvanica and $J$. javanica as subspecies of J. hutchinsiae.
Fig. 1 Distribution of Jubula hutchinsiae subsp. caucasica Konstant. \& Vilnet. Circles show specimes seen by the authors; triangles mark literature records (sub J. pennsylvanica).

Based on the treatment of Katagiri et al. (2010) Caucasian plants cannot be referred to $J$. javanica because they have relatively large male branches and lack thickened cell walls of the medula in the stem cross section. The Caucasian plants are morphologically very similar to $J$. pennsylvanica, which was Zerov's (1953) reason for treating them as $J$. pennsylvanica.

To determine better where our Caucasian samples should be referred, we sequenced the ITS12 nrDNA, trnL-F and trnG cpDNA loci and analyzed the results together with sequences obtained for Jubula by Pätsch et al. (2010). This brought us to an unexpected solution.

\section{MATERIALS AND METHODS}

Taxon sampling. The ITS1-2 nrDNA, trnL$\mathrm{F}$ and $\operatorname{trn} \mathrm{G}$ cpDNA loci of seven samples of Jubula gathered in the Russian part of the Caucasus, a single sample of Jubula pennsylvanica from the U.S.A., J. javanica from South Korea and $J$. japonica from the Russian Far East were sequenced as a part of this study. In addition we borrowed ITS1-2 and trnL-F nucleotide sequences of eighteen accessions belonging to five $\mathrm{Jubu}$ la subspecies from the study of Pätsch et al. (2010) deposited in GenBank. We followed these authors using the phylogenetically closely allied Nipponolejeunea pilifera and $N$. subalpina as an outgroup. All analyzed samples are listed in Table 1, including GenBank accession numbers and voucher details.

DNA isolation, PCR amplification and DNA sequencing. DNA was extracted from dried liverwort tissue using the NucleoSpin Plant Kit (Macherey-Nagel, Germany). The amplification and sequencing were performed using primers suggested by Taberlet et al. (1991), Shaw et al. (2005), and White et al. (1990) for the trnL-F, trnG-intron, and ITS1-2 regions, respectively.

PCR were carried out in $20 \mu \mathrm{l}$ volumes according to the following procedure: $3 \mathrm{~min}$ at $94^{\circ} \mathrm{C}, 30$ cycles $\left(30 \mathrm{~s} 94^{\circ} \mathrm{C}, 40 \mathrm{~s} 58^{\circ} \mathrm{C}, 60 \mathrm{~s} 72^{\circ} \mathrm{C}\right)$ and $2 \mathrm{~min}$ of extension time at $72^{\circ} \mathrm{C}$. Amplified fragments were visualized on $1 \%$ agarose TAE 
Table 1. The list of subspecies of Jubula hutchinsiae, specimen vouchers and GenBank accession numbers for ITS and $\operatorname{trn} \mathrm{L}-\mathrm{F} / \operatorname{trn} \mathrm{G}$. Accessions beginning with JN were produced for this study.

\begin{tabular}{|c|c|c|c|}
\hline subspecies & Specimen voucher & ITS & $\operatorname{trn} \mathrm{L}-\mathrm{F} / \operatorname{trn} \mathrm{G}$ \\
\hline bogotensis & Costa Rica: Puntarenas, Gradstein 9449 (GOET) & FN396817 & FN398012 \\
\hline bogotensis & Mexico: Veracruz, Gradstein s.n. (GOET) & FN396818 & FN398013 \\
\hline caucasica & $\begin{array}{l}\text { Russia: Caucaus 1, Cherkesskyi Pereval, } \\
\text { Konstantinova \& Savchenko K371-1-08 (KPABG) }\end{array}$ & JN836958 & JN836968/ JN836978 \\
\hline caucasica & $\begin{array}{l}\text { Russia: Caucaus 2, Sochi River, } \\
\text { Konstantinova \& Savchenko K446-7-08 (KPABG) }\end{array}$ & JN836959 & JN836969/ JN836979 \\
\hline caucasica & $\begin{array}{l}\text { Russia: Caucaus 3, Baranovka, } \\
\text { Konstantinova \& Savchenko K462-1-08 (KPABG) }\end{array}$ & JN836960 & JN836970/ JN836980 \\
\hline caucasica & $\begin{array}{l}\text { Russia: Caucaus 4, middle course of Shakhe River, } \\
\text { Konstantinova \& Savchenko K429-3-08 (KPABG) }\end{array}$ & JN836961 & JN836971/ JN836981 \\
\hline caucasica & $\begin{array}{l}\text { Russia: Caucaus 5, Belaya River, } \\
\text { Konstantinova K 463-1-07 (KPABG) }\end{array}$ & JN836962 & JN836972/ JN836982 \\
\hline caucasica & $\begin{array}{l}\text { Russia: Caucaus 6, lower course of Shakhe River, } \\
\text { Konstantinova \& Savchenko K443-14-08 (KPABG) }\end{array}$ & JN836963 & JN836973/ JN836983 \\
\hline caucasica & $\begin{array}{l}\text { Russia: Caucaus 7, Guzeripl', } \\
\text { Konstantinova, K456-5-07 (KPABG) }\end{array}$ & JN836964 & JN836974/JN836984 \\
\hline hutchinsiae & $\begin{array}{l}\text { Portugal: Madeira 1, } \\
\text { Schaefer-Verwimp \& Verwimp } 25675 \text { (GOET) }\end{array}$ & FN396811 & FN397099 \\
\hline hutchinsiae & $\begin{array}{l}\text { Portugal: Madeira 2, } \\
\text { Schaefer-Verwimp \& Verwimp } 25796 \text { (GOET) }\end{array}$ & FN396812 & FN398009 \\
\hline hutchinsiae & United Kingdom: Devon, Long 29077 (GOET) & FN396813 & FN398010 \\
\hline hutchinsiae & United Kingdom: Wales, Long 35296 (GOET) & FN396814 & FN398011 \\
\hline japonica & Japan: Miyazaki, Gradstein \& Mizutani 2958 (GOET) & FN396810 & FN397098 \\
\hline japonica & Russia: Primorsky Kray, Bakalin P-68-10-08 (KPABG) & JN836967 & JN836977/ JN836987 \\
\hline javanica & South Korea, Bakalin Kor-12-6-08 & JN836966 & JN836976/ JN836986 \\
\hline javanica & $\begin{array}{l}\text { Malaysia: Pahang, } \\
\text { Schaefer-Verwimp \& Verwimp 18870/A }\end{array}$ & FN396802 & FN397094 \\
\hline javanica & China: Yunnan, Long 34765 (GOET) & FN396805 & FN397095 \\
\hline javanica & China: Fujian, Zhu 555 (HSNU) & FN396806 & FN397096 \\
\hline javanica & Viet Nam: Vin-Phuc, Pocs \& Tran Ninh 98103/A2 (GOET) & FN396808 & FN397097 \\
\hline pennsylvanica & on \& Risk 2537 (UNAF) & FN396820 & 8014 \\
\hline pennsylvanica & U.S.A.: West Virginia, Davison 5201 (UNAF) & FN396821 & FN398015 \\
\hline pennsylvanica & U.S.A.: Alabama 1, Davison 4707 (UNAF) & FN396822 & FN398016 \\
\hline pennsylvanica & U.S.A.: Alabama 2, Davison 3775a (UNAF) & FN396823 & FN398017 \\
\hline pennsylvanica & U.S.A.: Alabama 3, Davison 4690 (UNAF) & FN396824 & FN398018 \\
\hline pennsylvanica & U.S.A.: North Carolina 1, Hyatt 8212 (UNAF) & FN396825 & FN398019 \\
\hline pennsylvanica & U.S.A.: North Car & FN396826 & FN398020 \\
\hline pennsylvanica & U.S.A.: Massachusetts, Konstantinova ACH-3-92 (KPABG) & JN836965 & JN836975/ JN836985 \\
\hline Outgroup spec & & & \\
\hline Nipponolejeunea & pilifera Japan, Higuchi 41359 & AY776307 & AY776310 \\
\hline N. subalpina & Japan 1, Ohnishi 5611 (HIRO) & DQ987289 & FJ380227 \\
\hline N. subalpina & Japan 2, Higuchi 41358 & AY776306 & AY776311 \\
\hline
\end{tabular}

gels by EthBr staining, purified using the $\mathrm{GFX}^{\mathrm{TM}}$ PCR DNA and Gel Band Purification Kit (Amersham Biosciences, U.S.A.), and then used as a template in sequencing reactions with the $\mathrm{ABI}$ Prism BigDye Terminator Cycle Sequencing Ready Reaction Kit (Applied Biosystems, U.S.A.) following the standard protocol provided for 3100 Avant Genetic Analyzer (Applied Biosystems, U.S.A.).
Phylogenetic analyses. The nucleotide alignments for ITS1-2, trnL-F and $\operatorname{trn} \mathrm{G}$ were obtained and manually corrected in BioEdit 7.0.1 (Hall, 1999). The $\operatorname{trn} \mathrm{G}$ alignment for ten samples sequenced by us was only used to study sequence variability. The ITS1-2 and $t r n \mathrm{~L}-\mathrm{F}$ alignments included 31 samples and were used for phylogenetic reconstructions. The variability of each 
Fig. 2. Maximum parsimony phylotion. genetic tree for Jubula hutchinsiae based on combined ITS1-2+trnL-F dataset. Bootstrap support values higher than 50 are indicated. Samples marked by asterisk required careful morphological investigation for robust determina-

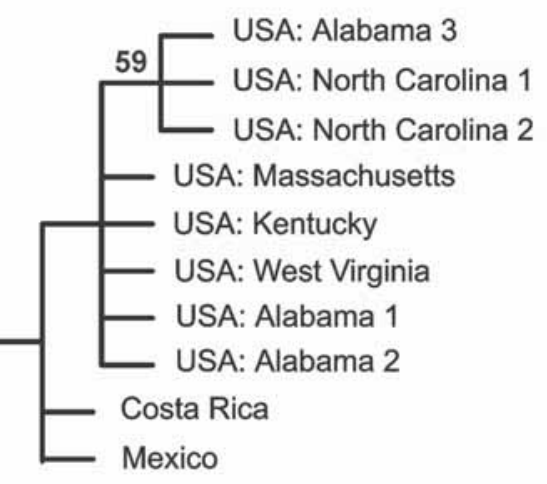

- Russia: Caucasus 1

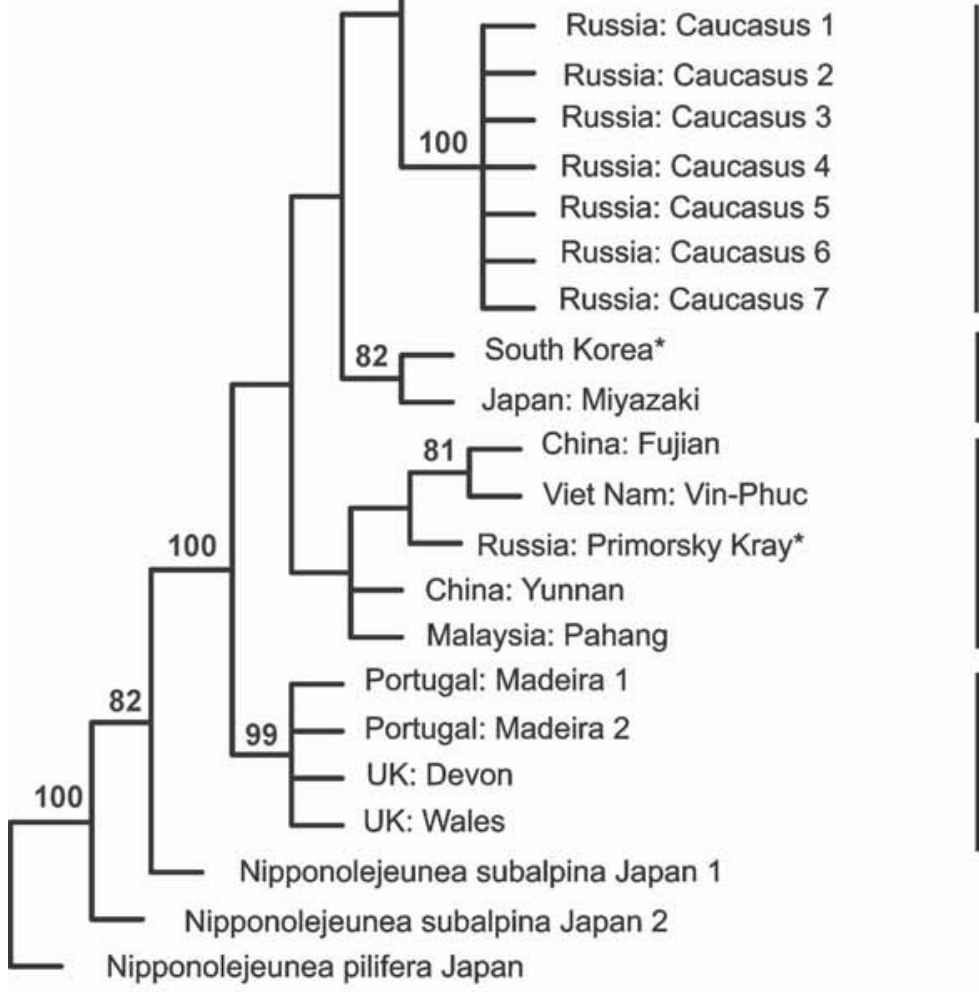

Ssp.pennsylvanica

Ssp.bogotensis

Ssp.caucasica

Ssp.japonica

Ssp.javanica

Ssp.hutchinsiae
DNA locus within and between taxa was evaluated as means of $p$-distances calculated in Mega 3.0 (Kumar et al., 2004), using pairwise deletion option for counting gaps.

Reconnaissance phylogenetic analyses didn't reveal any incongruence between ITS1-2 and trnL$\mathrm{F}$ datasets and both matrices were combined. With the exception of an ambiguously aligned P8 stemloop region in the trnL-intron all positions of alignment were included in the phylogenetic analyses.

Two analytical procedures for phylogenetic calculations were implemented: the maximum parsimony method (MP) with TNT v. 1.1 (Goloboff et al., 2003) and the maximum likelihood method with PhyML (Guindon \& Gascuel, 2003).

The parsimony analysis with TNT involved a New Technology Search with search minimal length tree by five reiterations and 1000 bootstrap resamplings, the default settings were used for the other parameters. Gaps in alignment were treated as missing data.

The best-fit evolutionary model of nucleotide substitutions, TN93, was determined using the ModelGenerator software (Keane et al., 2004). These models of nucleotide substitutions and four gamma rate categories were employed to estimate 


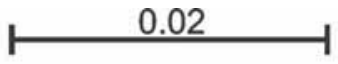

Fig. 3. Maximum likelihood phylogenetic tree for Jubula hutchinsiae based on combined ITS1-2+trnL-F dataset. Bootstrap support values higher than 50 are indicated. The length of the cut phylum is shown. Samples marked by asterisk required careful morphological investigation for more exact identification.

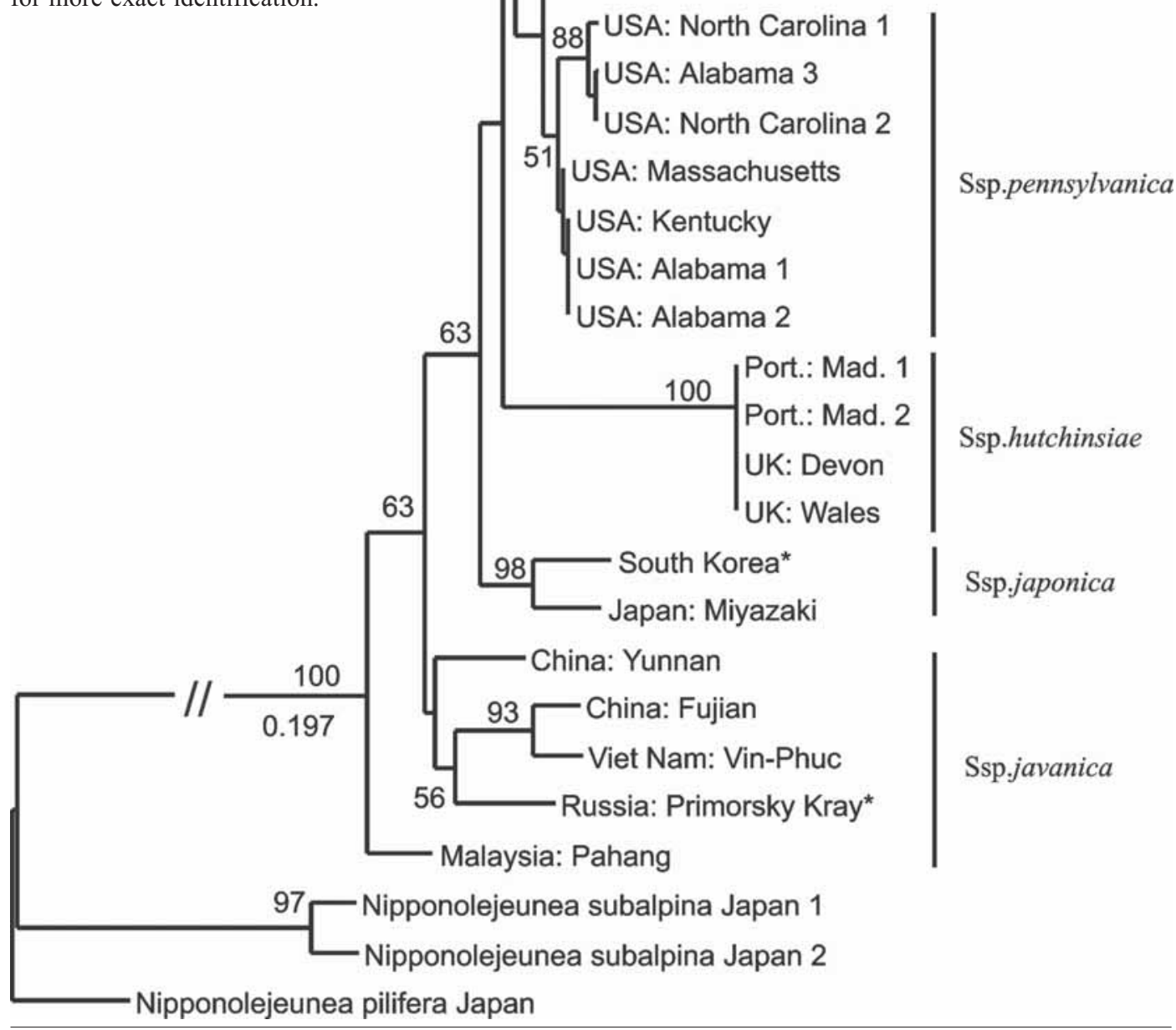

phylogeny by the ML method. Bootstrap supports (BS) for individual nodes were assessed using a resampling procedure with 500 replicates.

The haplotype diversity within the studied taxa of Jubula was estimated by TCS v.1.21 (Clement et al., 2000).

\section{RESULTS}

Phylogenetic reconstructions. The ITS1-2 alignment for 31 samples consists of 1039 sites, the $\operatorname{trn} \mathrm{L}-\mathrm{F}$ of 435 sites. The number of constant positions in ITS1-2/trnL-F alignments are 726 $(69.87 \%) / 394(90.57 \%)$, variable positions are 
$274(26.37 \%) / 35(8 \%)$, parsimony informative positions are $111(10.68 \%) / 32(7.36 \%)$ respectively. The combined ITS1-2+trnL-F alignment among 1476 sites is characterized by 309 (21\%) variable and $143(9.7 \%)$ parsimony informative positions. The trn $\mathrm{G}$ alignment for ten samples counted 703 sites, among them 680 (96.73\%) positions are constant, $19(2.7 \%)$, variable and 6 $(0.85 \%)$ parsimony informative.

The MP analysis yielded 7 equally parsimonious trees with a length of 366 steps with $\mathrm{CI}=$ 0.920981 and $\mathrm{RI}=0.923885$ calculated in Mega 3. The MP tree with means of bootstrap support is shown in Fig. 2. The ML calculation resulted in a single tree (Fig. 3), the arithmetic means of Log likelihood was -3952.962446 . All bootstrap supports with mean values higher than $50 \%$ are shown in Figs. 2-3.

The backbone topologies of both trees are different and only slightly supported. In contrast with Pätsch et al. (2010), the MP topology is characterized by unsupported polytomy and in ML topology some basal clades have support. On both MP and ML trees the clade of J. hutchinsiae subsp. hutchinsiae is supported (99\% and 100\% BS correspondingly). Caucasian samples of Jubula composed a clade with $100 \%$ BS support sister to the clade formed by $J$. hutchinsiae subsp. pennsylvanica $+J$. hutchinsiae subsp. bogotensis clade in both trees. Unfortunately we didn't achieve reliable support for the relation of the two latter subspecies as was the case in Pätsch et al. (2010). Support values higher than 50\% were obtained for clades $J$. hutchinsiae subsp. japonica $(82 \%$ MP, 98\% ML), J. hutchinsiae subsp. hutchinsiae (99\% MP, 100\% ML) and J. hutchinsiae subsp. pennsylvanica (51\% ML).

Molecular variability and haplotypes within Jubula subspecies. The subspecies of Jubula differ by nucleotide sequence length of the studied DNA loci (Table 2). The shortest ITS1-2 sequences belong to J. hutchinsiae subsp. hutchinsiae, 905 bp for both samples from Portugal and $911 \mathrm{bp}$ for samples from the United Kingdom. The Caucasian samples of Jubula have 914 bp in the ITS1-2 sequences. The length of ITS1-2 sequences for the other four subspecies is larger ranging from 918 to 922 nucleotides. The absence of $\operatorname{trn} \mathrm{L}-\mathrm{F}$ length variability is found for $J$. hutchinsiae subsp. japonica (429 bp), J. hutchinsiae subsp. pennsylvanica (434 bp) and $J$. hutchinsiae subsp. hutchinsiae (435 bp). The length of trnL-F sequences of Caucasian samples of Jubula is 443 except for sample K371-108 (KPABG) which has a deletion of four nucleotides in the P8 stem-loop region of the trnLintron.

The p-distances calculated for the ITS1-2 dataset suggest the low level of nucleotide substitutions for Caucasian samples of Jubula (0$0.1 \%$ ) and $J$. hutchinsiae subsp. hutchinsiae $(0 \%)$, and the high level for $J$. hutchinsiae subsp. javanica (0.4-2.5\%). The diversity between species varies from 1.0 to $4.1 \%$ by ITS1-2 (Table 3 ). Nucleotide substitutions in the $\operatorname{trn} \mathrm{L}-\mathrm{F}$ sequences were found only in J. hutchinsiae subsp. javanica (p-distances $0.5-1.6 \%$ ). In the whole the $\operatorname{trn} \mathrm{L}$ sequence diversity between Jubula taxa is much lower and ranges from 0.2 to $1.4 \%$.

Both substitutions and indels provide the haplotype diversity in Jubula. The highest haplotype diversity by both loci is found for $J$. hutchinsiae subsp. javanica (five haplotypes), whereas North American J. hutchinsiae subsp. pennsylvanica has eight haplotypes for the ITS1-2 loci and a single trnL-F-haplotype. ITS1-2 haplotype differences are found between Portuguese and British populations of $J$. hutchinsiae subsp. hutchinsiae with a common trnL-F-haplotype. The ITS12 sequence variability of Caucasian samples of Jubula consists of a single substitution in the second spacer that produced two haplotypes. The deletion of four nucleotides in the P8 stem-loop region of the trnL-intron in a single Caucasian sample also revealed two trnL-F haplotypes, at the same time there are no mutations in the $\operatorname{trn} \mathrm{G}$ sequences. It should be mentioned that each of three mutations was found in three different samples.

\section{DISCUSSION}

The overlapping values of DNA sequence variability within and between taxa of Jubula (Table 3) gives us an additional reason to agree with Pätsch et al. (2010) and accept Jubula hutchinsiae as a polymorphous species with geographically isolated subspecies. The samples of each subspecies composed clades on the obtained trees (except J. hutchinsiae subsp. javanica in the ML tree) but relations between them are unresolved 
Table 2. The means of nucleotide sequence length and number of haplotypes for each subspecies Jubula hutchinsiae, calculated from the all studied loci (n: number of samples).

$\begin{array}{llllll}\text { subspecies } & \mathrm{n} & \text { ITS, bp } & \text { ITS haplotypes } & \text { trnL-F, bp } & \text { trn L-F haplotypes } \\ \text { bogotensis } & 2 & 918-919 & 2 & 435-437 & 2 \\ \text { caucasica } & 7 & 914 & 2 & 439-443 & 2 \\ \text { hutchinsiae } & 4 & 905-911 & 3 & 435 & 1 \\ \text { japonica } & 2 & 918-919 & 2 & 429 & 1 \\ \text { javanica } & 5 & 918-922 & 5 & 437-444 & 5 \\ \text { pennsylvanica } & 8 & 918-922 & 8 & 434 & 1\end{array}$

or poorly supported as also was stated in Pätsch et al. (2010). The $100 \%$ BS supported clade of Caucasian samples is sister to clade of J. hutchinsiae subsp. pennsylvanica $+J$. hutchinsiae subsp. bogotensis but without support on both trees. The low level of sequence variability in the Caucasian samples of Jubula revealed only two haplotypes in ITS1-2 and trnL-F loci compared to the more variable $J$. hutchinsiae subsp. javanica (five haplotypes in ITS1-2 and trnL-F) and J. hutchinsiae subsp. pennsylvanica (eight haplotypes in ITS1-2 and one in trnL-F). Thus Caucasian samples are strongly separated from the other Jubula subspecies.

Plants from the Caucasus differ from subsp. javanica in 1) totally entire margins of dorsal lobes vs. sometimes 1-2 spinose dentate in subsp. javanica; 2) large male inflorescences, usually longer and wider than the dorsal lobes vs. small male inflorescences, usually shorter and narrower than the dorsal lobes in subsp. javani- ca; 3) absence of gemmae vs. presence of discoid gemmae on the dorsal surface of the dorsal lobes in subsp. javanica; 4) thin-walled cells of the medulla in the cross-section of stem vs. thickwalled in subsp. javanica. Specimens from the Caucasus differ from $J$. hutchinsiae subsp. hutchinsiae in 1) often rounded to apiculate, entiremargined leaves; 2) the lack of a spur in the lobules; 3) entire-margined underleaves; 4) entiremargined bracts and bracteoles.

It is harder to distinguish Caucasian plants from subsp. pennsylvanica. The subspecies caucasica differs from subsp. pennsylvanica in: 1) generally slightly smaller lobes; 2) underleaves that are often only slightly elevated from the stem with lobes more or less flat or only slightly incurved at the base and shortly decurrent (less than the width of the stem) vs. strongly elevated underleaves with strongly incurved and longly decurrent lobes (more than the width of the stem) in subsp. pennsylvanica; 3) slightly reflexed ba-

Table 3. The means of $p$-distances, calculated from ITS1-2 and trnL-F, within and between subspecies of Jubula hutchinsiae.

\begin{tabular}{|c|c|c|c|c|c|c|}
\hline $\begin{array}{l}\text { ITS1-2 } \\
\text { caucasica }\end{array}$ & $\begin{array}{l}\text { caucasica } \\
0-0.1\end{array}$ & javanica & japonica & hutchinsiae & bogotensis & pennsylvanica \\
\hline javanica & $2.0-3.4$ & $0.4-2.5$ & & & & \\
\hline japonica & $2.3-2.7$ & $1.8-3.1$ & 1.6 & & & \\
\hline hutchinsiae & $1.6-3.3$ & $1.1-4.1$ & $1.1-3.6$ & 0 & & \\
\hline bogotensis & $2.2-2.9$ & $2.1-3.7$ & $2.0-2.7$ & $2.2-3.6$ & 1.8 & \\
\hline pennsylvanica & $1.3-1.9$ & $2.2-4.8$ & $2.1-3.2$ & $0.8-3.8$ & $1.3-3.2$ & $0-1.3$ \\
\hline $\operatorname{trn} \mathrm{L}-\mathrm{F}$ & caucasica & javanica & japonica & hutchinsiae & bogotensis & pennsylvanica \\
\hline caucasica & 0 & & & & & \\
\hline javanica & $1.4-2.1$ & $0.5-1.6$ & & & & \\
\hline japonica & 1.2 & $0.5-1.4$ & 0 & & & \\
\hline hutchinsiae & $1.2-1.4$ & $0.9-2.1$ & 0.9 & 0 & & \\
\hline bogotensis & $0.93-1$ & $0.2-1.2$ & 0.2 & 0.9 & 0 & \\
\hline pennsylvanica & $0.9-1$ & $0.2-1.2$ & 0.2 & 0.9 & 0 & 0 \\
\hline
\end{tabular}


ses of sinus and non-reflexed margins of sinus of bracts and bracteoles vs. strongly reflexed bases and margins in bracts and bracteoles in subsp. pennsylvanica; 4) distinct small-celled zone between decurrent lobes of underleaves vs. indistinct or even absent in subsp. pennsylvanica. The subspecies pennsylvanica has ecology very similar to that of the Caucasian plants occuring in deep shaded wet ledges and walls of ravines, "on damp to dripping wet rocks" (Schuster, 1992).

The Caucasus is a strongly isolated mountain system with some sites that never were glaciated. As a result several centers of the tertial flora are preserved in the Caucasus (Pavlov, 1948). Some areas of Kolchida (also known as Colchis) with relict flora are restricted to the western Caucasus where many Caucasian endemic taxa of vascular plants occur. Jubula hutchinsiae subsp. caucasica was collected in just such areas. In particular it was found associated with Rhododendron ponticum, Ruscus colchicus, Laurocerasus officinale and another members of the flora of Colchis. It is reasonable to suppose a considerable and prolonged isolation of Caucasian populations of Jubula along with another Tertiary relic in the refugiums of the western Caucasus. The nearest localities of J. hutchinsiae subsp. hutchinsiae are mostly in coastal areas of southern Atlantic countries and on the Atlantic coast of Britain, Ireland and France. The nearest locality in Asia (as J. pennsylvanica) is in Himalaya (Dey et al., 2011). It is an amazing example of very slow evolution of liverwort species that evidently have diverged very little since Tertiary time.

\section{DESCRIPTION}

Jubula hutchinsiae subsp. caucasica Konstant. \& Vilnet subsp. nov. Figs. 4-5.

Subspecies haec Jubulae hutchinsiae subsp. pennsylvanicae marginibus loborum dorsalium amphigastriarumque integerrimis et statura androeciarum similis sed lobis amphigastriarum non reflexis et minus decurrentibus, zona inter lobos decurrentes amphigastriarum e cellulis minoribus formata et sequentiis DNA recedit.

Similar to Jubula hutchinsiae subsp. pennsylvanica in almost totally entire margins of dorsal lobes and underleaves as well as the size of male inflorescence but differs in non-reflexed and less decurrent lobes of underleaves, presence of distinct small-celled zone between decurrent lobes of underleaves and in DNA sequences.

Type: RUSSIA, Republic of Adygea, right bank of the Belaya River in surroundings of Guseripl' Town, cliffs on bank of small rivulet (435' $\left.30^{\prime \prime} \mathrm{N}-40^{\circ} 08^{\prime} 06^{\prime \prime} \mathrm{E}\right), 682 \mathrm{~m}$ alt., the bottom of cliffs near water level, on rock and among mosses, 17.X.2007, Konstantinova \# K463-1-07 (holotype KPABG, isotypes MW, MHA, VLA, LE).

Plants prostrate, light green in upper parts of shoots to dull or olive-green and dark green in the middle and at the base of shoots, some plants brown or blackish green especially in older parts, in the field mats often become dark green-blue because of presence of blue algae in lower parts of shoots, leafy shoots (1.0-)1.2-1.8 mm wide, $10-20 \mathrm{~mm}$ long, rhizoids from underleaf bases of few underleaves (bases of most underleaves without any trace of rhizoids), in clusters, light to dark brown, rarely colorless, ca. 5-7 $\mu \mathrm{m}$ wide, widened and branched at the end. Ventral cortical cells of stem rectangular, 19-22(-28) $\mu$ m wide and (30-)36-44(-66) $\mu \mathrm{m}$ long, rarely nearly quadrate and then $25-28 \times 25-28 \mu \mathrm{m}$, with light brownish, relatively thick walls, between decurrent lobes of underleaves with distinct small-celled zone consisting of thin-walled cells $8-9 \times 11-16 \mu \mathrm{m}$. Stem in cross section (80-)110-150 $\mu \mathrm{m}$ high and 150-180(-230) $\mu \mathrm{m}$ wide, 5-7 cells high, cells of medulla isodiametric to slightly elongated (15-) 24-28(-30)×(19-)22-30(-36) $\mu \mathrm{m}$, central cells thin-walled, one layer near cortical cells slightly thick-walled and often with light brown walls of cells, cortical cells $15-20 \times 20-22 \mu \mathrm{m}$, with thick brown walls. Branches of Frullania-type, with associated stem leaves without lobules, several small (sometimes hidden under leaves) sterile

Fig. 4. Jubula hutchinsiae subsp. caucasica Konstant. \& Vilnet (from the holotype): 1 - Autoicous plant with ventral innovations; 2 - part of shoot with male branch; 3 - part of shoot with perianth; 4 - leaves: a: with galeate lobule; $b$ : with explanate lobule; 5 - underleaves; 6-7-distal part of underleaves with teeth on lateral margin; 8 - apices of dorsal lobes; 9 - median cells of lobe; 10 - stem transverse section; 11 - elaters over capsule wall; 12 - female bracteole; 13 - female bract; 14 - male bract. 


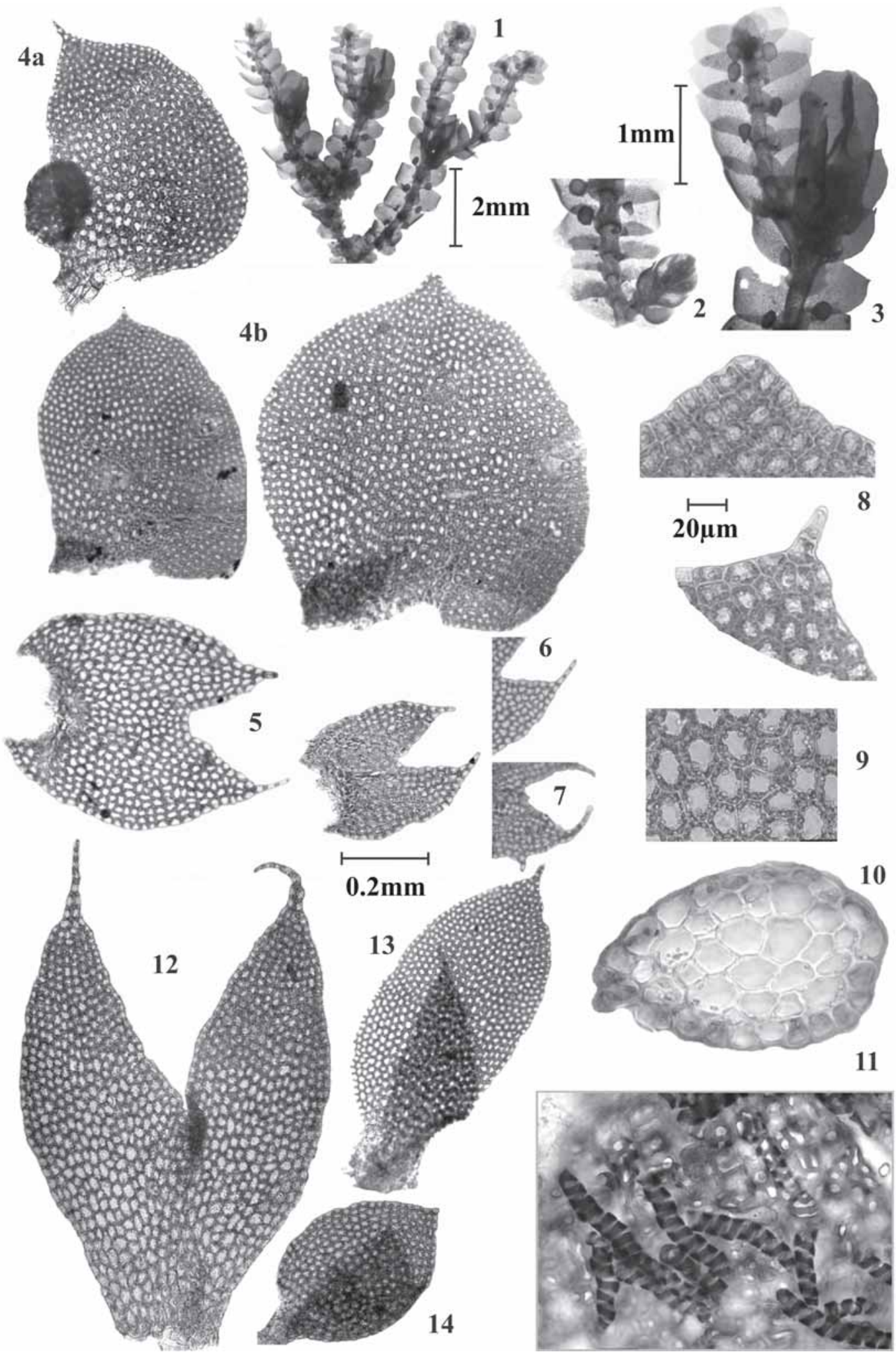



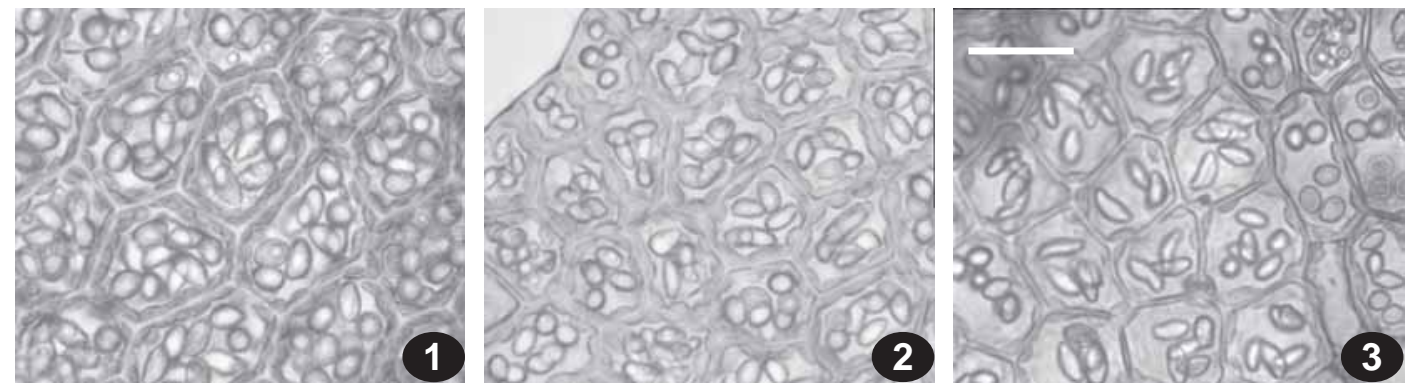

Fig. 5. Jubula hutchinsiae subsp. caucasica Konstant. \& Vilnet (from \#K364-11), oil-bodies: 1 - in the mid-leaf cells, 2 - in marginal cells, and 3 - in lobule cells. Scale bar $20 \mu \mathrm{m}$.

Lejeunea-type branches often present, the subfloral innovations are always of Frullania-type. Leaves imbricate, dorsal lobes flat to slightly convex, (350-)450-520(-600)×(570-)650-740(-800) $\mu \mathrm{m}$, ovate to semicordate and with convex dorsal side, apices distinctly incurved, sometimes rounded or blunt, but more often acute or apiculate with uniseriate apex 1-3 (-4) cells long, often 2-celled at base. Cells of apical tooth usually isodiametric or slightly elongated, $11 \times 14 \mu \mathrm{m}$, apical cells to $11 \times 22 \mu \mathrm{m}$. Cells thin-walled, with or without minute trigones, median cells (14-)15$18(-22) \times 17-25(-27) \mu \mathrm{m}$, basal cells $17-20$ $\times(25) 28-34(-37) \mu \mathrm{m}$. Oil bodies (7-)8-10 per cell, colorless, sphaeric, fusiform to narrowly ellipsoidal, 4-5 $\times 7-10 \mu \mathrm{m}$, with admixture of smaller, 2.5-3 $\times 4-5 \mu \mathrm{m}$, widely ellipsoidal ones; in marginal cells oil bodies (2-)3-4(-5), small, sphaeric to widely ellipsoidal, ca. $3 \times 3-5 \mu \mathrm{m}$. Lobules galeate and explanate, when galeate then obovate, narrowed to the mouth, narrow, ca 1.5-2.2 times long as wide, (91-)110-160(-175) ×160-200(-220) $\mu \mathrm{m}$ or suborbicular and then $170 \times 230 \mu \mathrm{m}$ and orbicular, $170 \times 170 \mu \mathrm{m}$, in one specimen one lobule had appendage. Underleaves distant, inserted on arcuate line, longly decurrent, however less than stem width, more or less apressed, with flat or slightly concave sides, usually longer than wide or with length equal to width, $340-600 \times 400-700$ $\mu \mathrm{m}$, bilobed to $0.5-0.6$ of their length, sinus Uor $\mathrm{V}$ - shaped, more or less reflexed, lobes mostly connivent or erect, acuminate-ciliate, with uniseriate apex of 2-4 elongated cells to $50-100 \mu \mathrm{m}$ long, with cells $9-14 \times 22-35(-40) \mu \mathrm{m}$, cells in undivided part of underleaves leptodermous polyhedral, without or with minute trigones somewhat elongated, $19-22 \times 25-28 \mu \mathrm{m}$. Lateral mar- gins of underleaf sometimes with spinose teeth.

Gemmae unknown.

Autoicous. Male branches of Lejeunea-type, often situated at the base of shoot quite distant from perianth (in some specimens difficult to find, because evidently destroyed), to $600 \mu \mathrm{m}$ wide and $1400 \mu \mathrm{m}$ long, sometimes as wide as long, definitely broader than leaves. Androecia spicate, compact, 1-2(-3) times as long as dorsal lobe, and distinctly wider, ventricose, male branch in cross-section 4 cells thick, 85$100 \times 125 \mu \mathrm{m}$, with $16-17$ peripheral cortical cells, bracts in (3-)5-7 pairs, subequally bilobed, with ventral lobe only slightly smaller than dorsal one. Dorsal lobe of male bracts ovate, 200-300 $\mu \mathrm{m}$ wide and 285-460 $\mu \mathrm{m}$ long, bracteole similar to underleaves but smaller and with obtuse lobes never ending in cilia, divided usually to $1 / 3$ of their length, $285 \times 220 \mu \mathrm{m}$, antheridia with uniseriate stalk, 2 per bract. Female inflorescences terminal. Female bracts in 1-2 pairs, unequally bilobed, keeled, with slightly reflexed margin in the bottom of sinus, but with non-reflexed margins of sides of sinus, dorsal lobe lanceolate, (260-)300$520 \times 800-1200 \mu \mathrm{m}$, acute to apiculate, ending in 2-celled apex, uppermost cell $11 \times 25 \mu \mathrm{m}$, ventral lobe $230 \times 520 \mu \mathrm{m}$, with 3 -celled apices, uppermost cell $10-11 \times 28 \mu \mathrm{m}$. Bracteole free from bracts, with 2 equal lanceolate lobes, $500 \times 1140 \mu \mathrm{m}$ long and $700 \mu \mathrm{m}$ wide, usually with entire margins, sometimes with single teeth 4 cells long, with basal cell $14-15 \times 28 \mu \mathrm{m}$ and apical cell $12 \times 28 \mu \mathrm{m}$, bilobed to the 0.9 of the length, keeled, with subequal lanceolate acuminate lobes ending in 4-celled apex, upper cell of which $11 \times 28-30 \mu \mathrm{m}$. 
Perianths were seen in most studied specimens but they were sometimes masked by leaves, often not fertilized, exerted to 0.3 of their length, smooth, 600-800 $\mu \mathrm{m}$ wide and 1200-1600 $\mu \mathrm{m}$ long, trigonous in transverse section, with one sharp postical keel and two lateral keels suddenly contracted to the distinct beak $60 \times 60 \mu \mathrm{m}$ wide and to $95 \mu \mathrm{m}$ long, composed of (3-)4(-5) rows of cells, cells of 2-3 lower rows are nearly isodiametric, (8-)10-14 $\mu \mathrm{m}$, whereas cells of 2 upper rows elongated, $8-11 \times 17-20 \mu \mathrm{m}$, upper cells partly free, to $12 \times 25-28 \mu \mathrm{m}$. Sporophytes in some collections present, but usually juvenille, mature capsules rare. Open capsule with 4 valves and attached elaters were found in two specimens. Capsule wall 2-layered, outer cells with radial banded thickenings and inner cells with reticulate thickenings. Elaters unispiral, 10-11 $\mu \mathrm{m}$ long, with red-brown spiral band, 6-7 $\mu \mathrm{m}$ wide (Fig. 4: 11). Spores not seen. Most collections were gathered in late September to middle October, so sporophytes likely ripen in the late October to November.

Variation. The morphological variability of $J$. hutchinsiae subsp. caucasica is very low in the Caucasus. The subspecies can be easily recognized in the field due to the characteristic dark green to dark bluish green color and apiculate apex incurved to ventral side. The size of plants, leaves, underleaves, etc. is slightly variable. Single teeth at the margin of underleaves can be seen in some specimens (Fig. 4: 7).

Ecology. The subspecies occurs from 50 to $1000 \mathrm{~m}$ alt., on shaded moist rocks and moist cliffs covered by fine earth, mainly in deep shaded canyons near running water: along streams and waterfalls, sometimes between exposed roots and on soil along trails in Taxus \& Buxus woods. In pure mats or with Metzgeria conjugata, Apometzgeria pubescens, Calypogeia fissa, Plagiochila porelloides, and Scapania verrucosa.

Distribution. The range of the subspecies is restricted mainly to the western Caucasus (Fig. 1) where it has been reported from Russia, Abkhazia, and Georgia (Zerov, 1953, as J. pennsylvanica; Duda, 1982 as J. pennsylvanica; Konstantinova et al., 2002 and Konstantinova \& Savchenko, 2011 as J. hutchinsiae subsp. javanica). The records from Turkey, Iran and Asia Minor (Guerke, 1978) probably should be referred to this taxon too.

The species is clearly restricted to areas with relict flora of Kolkhida.

Selected specimens examined. RUSSIA, Republic of Adygea: valley of Molchepa River right tributary of the Belay River in surroundings of Guseripl' Town, mouth of Filimonovskiy Creek, $\left(43^{\circ} 59^{\prime} 45^{\prime \prime} \mathrm{N}-40^{\circ} 08^{\prime} 34^{\prime \prime} \mathrm{E}\right), 665 \mathrm{~m}$ alt., on a rock covered by fine earth in the bed of a stream, 16.X. 2007, Konstantinova \#K453-1-07 (KPABG); right bank of the Molchepa River, right tributary of the Belay River, in surroundings of Guseripl' Town (435' $\left.02 " \mathrm{~N}-40^{\circ} 08^{\prime} 53^{\prime \prime} \mathrm{E}\right), 835 \mathrm{~m}$ alt., on rock near waterfall, 18.X.2007, Konstantinova \#K471-2-07 (KPABG); valley of the Molchepa River, right tributary of the Belay River, in surroundings of Guseripl' Town, Filimonovskiy Creek, deep shaded can-

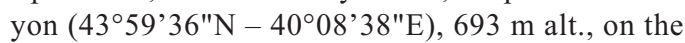
bank of a stream, on rock at the bottom of rock outcrop, 16.X.2007, Konstantinova \#K456-5-07 (KPABG); Krasnodar Territory: Right banks of the Vostochnyi Dagomys River near the Baranovka set-

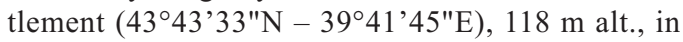
a deep canyon with small waterfalls, on moist rocks, 13.X.2008, Konstantinova \& Savchenko \#K462-108 (KPABG); valley of the Shakhe River, cliffs on the right bank of the Belyi Stream $\left(43^{\circ} 52^{\prime} 15^{\prime \prime} \mathrm{N}-\right.$ $\left.39^{\circ} 47^{\prime} 56^{\prime \prime} \mathrm{E}\right)$, ca. $450 \mathrm{~m}$ alt., on a ledge of rock, among mosses 2.X.2008, Konstantinova \& Savchenko \# K429-3-08 (KPABG); lower course of Shakhe River,

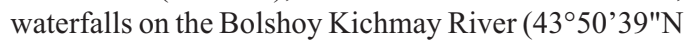
- 39³3’39"E), 193 m alt., on loamy soil in Buxus stands, 10.X.2008, Konstantinova \& Savchenko \#K443-14-08 (KPABG); same place (4350'20"N $\left.39^{\circ} 33^{\prime} 37^{\prime \prime} \mathrm{E}\right), 68 \mathrm{~m}$ alt., on a cliff on the right bank near the 4-th waterfall, 10.X.2008, Konstantinova \& Savchenko \#K443-5-08 (KPABG); Shakhe River basin, north facing cliffs on the left bank of the Bushuika River (435' $\left.29^{\prime \prime} \mathrm{N}-39^{\circ} 50^{\prime} 18^{\prime \prime} \mathrm{E}\right), 534 \mathrm{~m}$ alt., on rock, 28.IX.2008, Konstantinova \& Savchenko \#K4021-08 (KPABG); Valley of the Sochi River, slope to the first Orekhovskiy waterfall $\left(43^{\circ} 42^{\prime} 28^{\prime \prime} \mathrm{N}-39^{\circ} 46^{\prime}\right.$ 31 "E), $154 \mathrm{~m}$ alt., on roots and rocks in a deep niche, 11.X.2008, Konstantinova \& Savchenko \#K446-7-08 (KPABG).

\section{ACKNOWLEDGEMENTS}

We are greatly indebted to V. Bakalin for arranging loans from VLA; A. Savchenko is thanked for preparing distribution map, Anders Hagborg for checking English and valuable comments. We thank Dr. R. Ochyra for the transla- 
tion of the subspecies diagnosis into Latin. This work was partly supported by the RFBR 09-0400281 .

\section{LITERATURE CITED}

BROTHERUS, V.F. 1892. Enumeratio muscorum Caucasi. Hepaticae. - Acta Soc. Sci. Fenn. 19(12): 141-161.

CLEMENT, M., D. POSADA \& K.A. CRANDALL 2000. TCS: a computer program to estimate gene genealogies. - Molec. Ecology 9: 1657-1659.

DEY, M., D. SINGH \& D.K. SINGH 2011. Jubula pennsylvanica (Hepaticae: Jubulaceae) new to Asia. - Taiwania 56: 66-70.

[DUDA, J.] ДУДА Й. 1982. К распространению печеночных мхов на Кавказе - [Ad distributionem hepaticarum in Caucaso notula] Новости сист. низи. pacm. [Novosti Sist. Nizsh. Rast.] 19: 200-204.

DÜLL, R. 1983. Distribution of European and Macaronesian Liverworts (Hepaticophytina). - Bryol. Beitr. 2: 1-115.

GOLOBOFF, P., S. FARRIS \& K.NIXON 2003. TNT (Tree analysis using New Technology) (BETA) ver. 1.0. - Program and documentation, available from the authors, and at www.cladistics.com/aboutTNT.html.

GUERKE, W.R. 1978. A monograph of the genus Jubula Dumortier. - Bryophytorum Bibliotheca 17: 1-118.

GUINDON, S. \& O. GASCUEL 2003. A simple, fast, and accurate algorithm to estimate large phylogenies by maximum likelihood. - Syst. Biology 52: 696-704.

HALL, T. A. 1999. BioEdit: a user-friendly biological sequence alignment editor and analysis program for Windows 95/98/ NT. - Nucl. Acids. Symp. 41: 95-98.

KATAGIRI, T., T. YAMAGUCHI \& H. DEGUCHI 2010. Taxonomic studies on the liverwort Jubula Dumort. (Marchantiophyta: Jubulaceae) in Japan and Taiwan. - Hikobia 15: 463-472.

KEANE, T.M., T.J. NAUGHTON \& J.O. MCINERNEY 2004. ModelGenerator: amino acid and nucleotide substitution model selection. - National University of Ireland, Maynooth. http://bioinf.may.ie/software/modelgenerator/

KONSTANTINOVA N.A., T.V.AKATOVA \& A.N. SAVCHENKO 2009. Hepatics of the Caucasian state nature reserve (western the Caucasus, Russia). - Arctoa 18: 121-134

KONSTANTINOVA, N.A. \& V.A. BAKALIN 2009. Checklist of liverworts (Marchantiophyta) of Russia. - Arctoa 18: 1-63.

KONSTANTINOVA, N.A., A.D. POTEMKIN \& R.N. SCHLJAKOV 1992. Check-list of the Hepaticae and Anthocerotae of the former USSR. - Arctoa 1: 87-127.

[KONSTANTINOVA N.A. \& A.N. SAVCHENKO] KOHСТАНТИНОВА Н.А., А.Н.САВЧЕНКО 2011. К флоре печеночников Сочинского национального парка (Запад- ный Кавказ, Россия). - [To the liverwort flora of the Sochi National Park (Western the Caucasus, Russia)]Новости сист. низи. pacm. [Novosti Sist. Nizsh. rast.] 45 (in press).

KUMAR, S., K. TAMURA \& M. NEI 2004 MEGA3: Integrated software for Molecular Evolutionary Genetics Analysis and sequence alignment. - Briefings in Bioinformatics 5: 150-163.

[LAZARENKO, A.S.] ЛАЗАРЕНКО А.С. 1936. Очерк бриофлоры заповедника Горнотаежной станции АН СССР. - [Outline of bryoflora of Strict Nature Reserve of Mountain taiga Station of AN USSR] Труды Горнотаежной станции ДВФ АН СССР [Trudy Gornotaezhnoy stantsii Dalnevost. Fil. Akad. Nauk SSSR] 1: 93-107.

[PAVLOV, N.V.] ПАВЛОВ Н.В. 1948. Растительность мезофитных центров Кавказа и Талыша. - [Vegetation of epy mesophytic centers of the Caucasus and Talysh] $B \kappa н$. Ботаническая география CСCP [In: Botanicheskaya geografiya SSSR] Изд-во Акад. наук Казахской CCP, Алма-Ama [Izdatelstvo Akademii Nauk Kasakhskoj SSR, Alma-Ata]: 316-335.

PÄTSCH, R., J. HENTSCHEL, R. LINARES-PALOMINO, R.-L. ZHU \& J. HEINRICHS 2010. Diversification and taxonomy of the liverwort Jubula Dumort. (Jungermanniopsida: Porellales) inferred from nuclear and chloroplast DNA sequences. - Syst. Bot. 35: 6-12.

SCHUMACKER, R. \& J. VÁŇA 2005. Identification keys to the liverworts and hornworts of Europe and Macaronesia (distribution and status). 2nd edition fully revised and updated. Poznac, Sorus: 1-211

SCHUSTER, R.M. 1992. The Hepaticae and Anthocerotae of North America east of the hundredth meridian. Vol. 5. - Chicago, $854 \mathrm{pp}$.

SHAW, J., E.B. LICKEY, J. BECK, S.B. FARMER, W. LIU, J. MILLER, K.C. SIRIPUN, C. WINDER, E.E. SCHILLING \& R.L. SMALL 2005. The tortoise and the hare II: relative utility of 21 noncoding chloroplast DNA sequences for phylogenetic analysis. - Am. J. Bot. 92: 142-166.

TABERLET, P., L. GIELLY, G. PAUTOU \& J. BOUVET 1991. Universal primers for amplification of three non-coding regions of chloroplast DNA. - Plant Mol. Biol. 17: 1105-1109.

VERDOORN, F. 1930. Die Frullaniaceae der indomalesischen Inseln. De Frullaniaceis VII. - Annales Bryologici 1 (Supplement): 1-187.

WHITE, T.J., T. BRUNS, S. LEE \& J. TAYLOR 1990. Amplification and direct sequencing of fungal ribosomal RNA genes for phylogenetics. - In: Innis M.A., D.H. Gelfand, J.J. Snisky \& T.J. White (eds.) PCR protocols: a guide to methods and applications. San Diego, CA: 315-322.

[ZEROV, D.K.] ЗЕРОВ Д.К. 1953. Rid Jubula Dum. у флорі CPCP. - [The genus Jubula Dum. in flora of the USSR] Ботаніч. журн. [Bot. Zhurn. (Kiev)] 10(3): 85-90. 